\title{
Serotonin transporter activity of imidazolidine-2,4-dione and imidazo[2,1-f]purine-2,4-dione derivatives in aspect of their acid-base properties
}

\author{
Agnieszka Zagórska $\cdot$ Anna Czopek • Maciej Pawłowski • \\ Małgorzata Dybała • Agata Siwek • Gabriel Nowak
}

Received: 14 September 2011 / Accepted: 4 November 2011/Published online: 19 November 2011

(C) The Author(s) 2011. This article is published with open access at Springerlink.com

\begin{abstract}
Affinities of arylpiperazinylalkyl derivatives of imidazo[2,1-f]purine-2,4-dione and imidazolidine-2,4dione for serotonin transporter and their acid-base properties were evaluated. The dissociation constant $\left(\mathrm{p} K_{\mathrm{a}}\right)$ of compounds 1-22 were determinated by potentiometric titration and calculated using pKalc 3.1 module of the Pallas system. The data from experimental methods and computational calculations were compared and suitable conclusions were reached.
\end{abstract}

Keywords Dissociation constant - Imidazolidine-2, 4-dione - Imidazo[2,1-f]purine-2,4-dione ·

Serotonin receptor $5-\mathrm{HT}_{1 \mathrm{~A}} \cdot$ Serotonin transporter

\section{Introduction}

Studies on major depression, anxiety, schizophrenia, mania, autism, obesity, and drug addiction have implicated the involvement of serotonergic (5-HT) abnormalities in these diseases. Serotonin acts via receptors which were classified into seven families $\left(5-\mathrm{HT}_{1-7}\right)$ and at least 14 different subtypes (Barnes and Sharp, 1999; Filip et al., 2005; Hannon and Hoyer, 2008; Hoyer et al., 2002; Pauwels, 2003). The level of 5-HT in central nervous system (CNS) and regulation of its neurotransmission are

\footnotetext{
A. Zagórska $(\bowtie) \cdot$ A. Czopek · M. Pawłowski

Department of Pharmaceutical Chemistry,

Jagiellonian University Medical College, Medyczna 9 St,

30-688 Kraków, Poland

e-mail: azagorsk@cm-uj.krakow.pl
}

M. Dybała · A. Siwek · G. Nowak

Department of Pharmacobiology, Jagiellonian University

Medical College, Medyczna 9, 30-688 Kraków, Poland connecting with serotonin transporter (SERT). This transporter is mediated extracellular uptake of serotonin from the synaptic clefts. The SERT protein belongs to the large family of transporters that are dependent on $\mathrm{Na}^{+}$ions. Serotonin, $\mathrm{Na}^{+}$and $\mathrm{Cl}^{-}$form a quaternary complex with the transporter before being co-transported across the plasma membrane, followed by counter transport of $\mathrm{K}^{+}$. At physiological $\mathrm{pH}=7.4$, serotonin is protonated and in the case of the SERT 5-HT accumulation was not affected by transmembrane $\mathrm{pH}$ differences (Rudnick et al., 1989; Forrest et al., 2007). Many drug molecules contain ionizable groups and hence penetrate across cell membranes, through pores and via active transport mechanism in a $\mathrm{p} K_{\mathrm{a}}$ dependent fashion, therefore $\mathrm{p} K_{\mathrm{a}}$ is an important factor on estimating the pharmacological behavior of drugs and their pharmacokinetic. This is particularly important in physiological systems, where ionization state will affect the rate at which the compound is able to diffuse across membranes and obstacles such as the blood-brain barrier (BBB) (Luan et al., 2005; Manallack, 2007).

Since the early seventies until today, a large number of selective SERT inhibitors (SSRIs) have been described. However, only 5 products are currently marketed: fluoxetine $\left(\right.$ Prozac $\left.{ }^{\circledR}\right)$, escitalopram (Lexapro $\AA$, Cipralex $\AA$ ), sertraline (Zoloft $\left.{ }^{\circledR}\right)$, paroxetine (Paxil $\left.{ }^{\circledR}\right)$, and fluvoxamine (Feva$\operatorname{rin}\left({ }^{\circledR}\right)$. A major limitation of SSRIs and that extends to all other classes of antidepressants as well, is the 2-6 weeks delay in onset of therapeutic activity. This lengthy time to achieve remission is suspected to result from indirect activation of somatodendric 5-HT $1 \mathrm{~A}$ autoreceptors (Chaput et al., 1986; Invernizzi et al., 1992; Invernizzi et al., 1996). The latest direction taken in antidepressant drug discovery has been to design ligands with multiple targets. Preclinical data obtained by co-administrating a SSRI with selective $5-\mathrm{HT}_{1 \mathrm{~A}}$ antagonist, suggest that a single compound 
combining SSRIs with $5-\mathrm{HT}_{1 \mathrm{~A}}$ antagonism should have a favorable therapeutic utility in the treatment (Artigas et al., 1996; Ballesteros and Callodo, 2004; Adell et al., 2005; Morphy and Rankovic, 2005; Millan, 2006). The most important class of 5-HT $\mathrm{H}_{1 \mathrm{~A}}$ receptor ligands are derivatives of arylpiperazine. Simple arylpiperazines are non-selective ligands for 5-HT receptor. The good selectivity and affinity for $5-\mathrm{HT}_{1 \mathrm{~A}}$ receptors show the majority of 4-substituted arylpiperazines. These derivatives contain a flexible aliphatic chain of different length (long-chain arylpiperazines, LCAPs), which connects the arylpiperazine fragment with second terminal pharmacophoric group (Lopez-Rodriguez et al., 2002; Paluchowska et al., 2007; Paluchowska et al., 2005). For several years our attention has been focused on developing LCAPs containing a different amide/imide terminal fragment. In our earlier study a series of arylpiperazinylalkyl derivatives with a complex terminal part based on the purine moiety had been synthesized. Compounds with pyrimido- and imidazo-[2,1-f]purine-2, 4-dione fragment have been tested in vitro for their $5-\mathrm{HT}_{1 \mathrm{~A}}$ and $5-\mathrm{HT}_{2 \mathrm{~A}}$ receptor affinities and were potent $5-\mathrm{HT}_{1 \mathrm{~A}}$ receptor ligands with $K_{\mathrm{i}}$ within the range of 5.6-278 nM and demonstrated lack of affinity for $5-\mathrm{HT}_{2 \mathrm{~A}}$ subtype (Zagórska et al., 2009). The majority of imidazolidine-2,4-dione derivatives displayed high affinity for $5-\mathrm{HT}_{1 \mathrm{~A}}$ receptors (23-350 nM), and some of them exhibited significant affinity for 5- $\mathrm{HT}_{2 \mathrm{~A}}$ receptors (Czopek et al., 2010).

Continuing our research, we have been interested in affinities of arylpiperazinylalkyl derivatives of imidazo [2,1-f]purine-2,4-dione and imidazolidine-2,4-dione (hydantoin) for SERT and their acid-based properties presented as dissociation constant $\left(\mathrm{p} K_{\mathrm{a}}\right)$ values. The aqueous ionization constant of a molecule is denoted by its $\mathrm{p} K_{\mathrm{a}}$ values, where this constant is equivalent to the $\mathrm{pH}$ at which a given ionizable group on the molecule is half-ionized. In search of the structure activity relationship, the correlation with biological activity data with received $\mathrm{p} K_{\mathrm{a}}$ values, was done.

\section{Methods and materials}

\section{Chemistry}

The chemical structures of derivatives of the imidazo [2,1-f]purine-2,4-dione and imidazolidine-2,4-diones investigated are listed in the Table 1 . The hydrochloride salts of investigated compound 1-22 of the analytical purity (mp, TLC, elemental analysis) were used for the potentiometric titration.

Compounds 1-12 were obtained in the cyclocondensation reaction of 7-acetic-8-bromotheophylline aldehyde, 7-acetonyl-8-bromotheophylline, and 7-phenacyl-8-bromotheophylline, with double amount of appropriate arylpiperazinylpropylamine, in boiling 2-methoxyethanol (Zagórska et al., 2009). Whereas initial spirohydantoins were prepared from appropriate ketone by the BuchereBerg reaction with modification described by Goodson et al. (1960). Compounds 13-22 were obtained by a twostep procedure involving alkylation of hydantoin at N3 position and condensation of intermediates with the substituted arylpiperazine or tetrahydroizoquinoline. The synthesis and physicochemical properties are described elsewhere (Zagórska et al., 2009; Czopek et al., 2010). The synthetic procedures and physicochemical data of compounds 16, 17, 21, and 22 have not been published yet.

\section{Pharmacology in vitro}

The assay was performed according to the method of Owens et al. (1997) with slight modifications. [ $\left.{ }^{3} \mathrm{H}\right]-$ Citalopram (spec. act. $50 \mathrm{Ci} / \mathrm{mmol}$, NEN Chemicals) was used for labeling 5-HT-transporter. Rat cerebral cortex was homogenized in 30 volumes of ice-cold $50 \mathrm{mM}$ Tris- $\mathrm{HCl}$ containing $150 \mathrm{mM} \mathrm{NaCl}$ and $5 \mathrm{mM} \mathrm{KCl}, \mathrm{pH}=7.7$ at $25^{\circ} \mathrm{C}$ and centrifuged at $20,000 \times g$ for $20 \mathrm{~min}$. The supernatant was decanted and pellet was resuspended in 30 volumes of buffer and centrifuged again. The resulting pellet was resuspended in the same quantity of the buffer and centrifuged third time in the same conditions. $240 \mu \mathrm{l}$ of the tissue suspension, $30 \mu \mathrm{l}$ of $1 \mathrm{nM}\left[{ }^{3} \mathrm{H}\right]$-citalopram, and $30 \mu \mathrm{l}$ of the analyzed compound or $30 \mu \mathrm{l}$ of $1 \mu \mathrm{M}$ imipramine (displacer) were incubated at $22^{\circ} \mathrm{C}$ for $1 \mathrm{~h}$. The concentrations of analyzed compounds ranged from $10^{-10}$ to $10^{-5} \mathrm{M}$. Incubations were terminated by vacuum filtration over Whatman GF/B filters and washed 5 times with $200 \mu \mathrm{l}$ of ice-cold buffer. Radioactivity was measured in a MicroBeta TriLux- liquid scintillation counter (Perkin Elmer). All assays were done in duplicates.

Radioligand binding data were analyzed using iterative curve fitting routines (GraphPAD/Prism, Version 3.0 - San Diego, CA, USA). $K_{\mathrm{i}}$ values were calculated from the Cheng-Prusoff equation (Cheng and Prusoff, 1973). The results of in vitro binding studies $\left(\mathrm{p} K_{\mathrm{i}}\right)$ of the compounds (1-22) are shown in Table 1.

Measurement of $\mathrm{p} K_{\mathrm{a}}$

The $\mathrm{p} K_{\mathrm{a}}$ measurements were determined by potentiometric titration (alkalimetric), using a Compact Titrator Mettler Toledo G21 equipped with an integrated burette drive, and combined glass electrode DGi115-SC, compact rod stirrer, and $20 \mathrm{ml}$ burette. Titrator was pre-programmed with standard tried-and-tested methods and calculations. The $\mathrm{pH}$ 
Table 1 The structures of compounds 1-22, their SERT activity $\left(\mathrm{p} K_{\mathrm{i}}\right)$, experimental and theoretical $\mathrm{p} K_{\mathrm{a}}$ values<smiles>[R]CCCn1c([X])cn2c3c(=O)n(C)c(=O)n(C)c3nc12</smiles><smiles>[R]CCCN1C(=O)NC2(CCc3ccccc32)C1=O</smiles><smiles>[R]CCCN1C(=O)NC2(CCCc3ccccc32)C1=O</smiles><smiles>[X]c1cccc(N2CCNCC2)c1</smiles><smiles>[B]C1CCc2ccccc2C1</smiles>

\begin{tabular}{|c|c|c|c|c|c|c|c|}
\hline Compd & Core & $X$ & $\mathrm{R}$ & $\mathrm{Z}$ & $\mathrm{p} K_{\mathrm{i}}[\mathrm{SERT}]$ & $\operatorname{Exp} \mathrm{p} K_{\mathrm{a}}$ & $\mathrm{p} K_{\mathrm{a}}$ Pallas \\
\hline 1 & I & $\mathrm{H}$ & A & $\mathrm{H}$ & 6.35 & 8.09 & 9.29 \\
\hline 2 & I & $\mathrm{H}$ & A & $2-\mathrm{OCH}_{3}$ & 6.95 & 8.19 & 9.29 \\
\hline 3 & I & $\mathrm{H}$ & A & $3-\mathrm{Cl}$ & 7.53 & 8.35 & 9.20 \\
\hline 4 & I & $\mathrm{CH}_{3}$ & A & $\mathrm{H}$ & 4.95 & 7.55 & 9.29 \\
\hline 5 & I & $\mathrm{CH}_{3}$ & A & $2-\mathrm{OCH}_{3}$ & 5.09 & 7.61 & 9.29 \\
\hline 6 & I & $\mathrm{CH}_{3}$ & A & $3-\mathrm{Cl}$ & 7.52 & 8.12 & 9.20 \\
\hline 7 & I & $\mathrm{CH}_{3}$ & A & 2,3-diCl & 7.25 & 7.61 & 9.20 \\
\hline 8 & I & $\mathrm{CH}_{3}$ & B & - & 4.52 & 8.66 & 8.72 \\
\hline 9 & I & $\mathrm{C}_{6} \mathrm{H}_{5}$ & A & $\mathrm{H}$ & 6.65 & 8.79 & 9.29 \\
\hline 10 & I & $\mathrm{C}_{6} \mathrm{H}_{5}$ & A & $2-\mathrm{OCH}_{3}$ & 4.69 & 8.44 & 9.29 \\
\hline 11 & I & $\mathrm{C}_{6} \mathrm{H}_{5}$ & A & $3-\mathrm{Cl}$ & 6.72 & 10.61 & 9.20 \\
\hline 12 & I & $\mathrm{C}_{6} \mathrm{H}_{5}$ & B & $\mathrm{H}$ & 5.61 & 10.41 & 8.72 \\
\hline 13 & II & - & A & $\mathrm{H}$ & 5.96 & 10.48 & 8.95 \\
\hline 14 & II & - & A & $2-\mathrm{OCH}_{3}$ & 5.96 & 9.60 & 8.95 \\
\hline 15 & II & - & A & $3-\mathrm{Cl}$ & 6.07 & 10.31 & 8.85 \\
\hline 16 & II & - & A & $3-\mathrm{CF}_{3}$ & 6.19 & 9.96 & 8.95 \\
\hline 17 & II & - & B & - & $\mathrm{Nd}$ & 10.93 & 8.38 \\
\hline 18 & III & - & A & $\mathrm{H}$ & 6.00 & 10.55 & 8.95 \\
\hline 19 & III & - & A & $2-\mathrm{OCH}_{3}$ & 6.01 & 10.32 & 8.95 \\
\hline 20 & III & - & A & $3-\mathrm{Cl}$ & 6.04 & 10.80 & 8.85 \\
\hline 21 & III & - & A & $3-\mathrm{CF}_{3}$ & 5.62 & 11.08 & 8.95 \\
\hline 22 & III & - & B & - & 5.40 & 10.90 & 8.38 \\
\hline
\end{tabular}

electrode was first calibrated with buffers $(\mathrm{pH}=7.00$ and $\mathrm{pH}=9.00)$. Sample $\left(5 \times 10^{-5} \mathrm{M}\right)$ were prepared in water solutions (between 10-20 ml). Typically, more than 120 $\mathrm{pH}$ readings were collected for each titration. The deionized water used for the aqueous solution was twice distilled, degassed, and filtered with a Hydrolab Polska HLP5s System. The $0.0512 \mathrm{M}$ sodium hydroxide solution were prepared from substances delivered by POCH. The buffers $\mathrm{pH}=7.00$ and $\mathrm{pH}=9.00$ used for calibration were obtained from Beckman Coulter. The $\mathrm{p} K_{\mathrm{a}}$ were expressed as the mean of values of results from three titrations and are listed in Table 1.

The following equation was used for the calculation of the $\mathrm{p} K_{\mathrm{a}}$ values:

$\mathrm{p} K_{a}=\mathrm{pH}+\log \frac{2 C t-C a}{C a-C t}$ where $C t$ is a titrant concentration, $C a$ is a concentration of sample at each measured point.

\section{Calculations}

Calculations of $\mathrm{p} K_{\mathrm{a}}$ were performed using Pallas 3.1 (CompuDrug Chemistry Ltd, 1995). Program applied logarithm, adapted after Hammett and Taft takes into account all necessary electronic, steric, and other effects and relies on an extended database of almost a thousand equations.

Regression analysis was performed using the Statistica for Windows program (Statistica for Windows, version 9, Statsoft Inc.2009). The significance level of the performed calculations was above $95 \%$. 
Fig. 1 Correlation between $\mathrm{p} K_{\mathrm{a}}$ values and $\mathrm{pK}_{\mathrm{i}} \mathrm{SERT}$ of compounds 1-7 (left) and 13-22 (right)

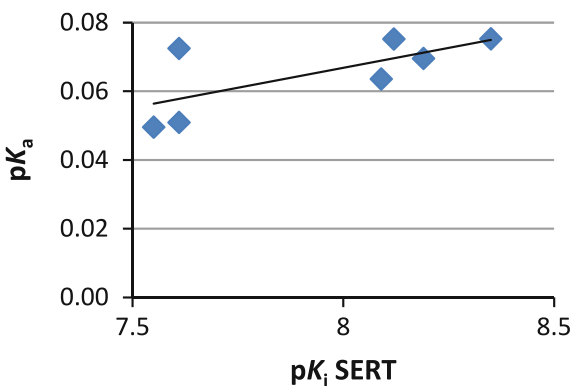

\section{Results and discussion}

The library consisting of twenty two compounds was investigated. Based on their structural features, this library could be divided into two sublibraries: the first contained various arylpiperazinylpropyl derivatives of imidazo[2,1$f$ ]theophylline, and the second derived from imidazolidine2,4-dione. Comparing the affinity for SERT obtained for imidazo[2,1-f]purine-2,4-dione and respective imidazolidine-2,4-dione analogues revealed higher activity in the first mentioned series. The most potent SERT ligands were compounds $3, \mathbf{6}$, and 7 with $\mathrm{p} K_{i}$ within the range of 7.25-7.53, which were containing 2,3-dichloro or 3-chlorophenylpiperazine fragment in their structures. Compounds $1,2,9,11,12,15,16,19$, and 20 displayed moderate to very low affinity for the SERT (5.61-6.95), whereas other were practically devoid of any affinity.

Furthermore experimental dissociation constants for investigated compounds were determined. It seems that the basicity of the compounds mainly depends on two basic nitrogen atoms in piperazine ring. In general, compounds containing a substituent at phenyl ring electro-attracting atom $(\mathrm{Cl})$ or group $\left(\mathrm{CF}_{3}\right)$ exhibited higher experimental $\mathrm{p} K_{\mathrm{a}}$ values than unsubstituted ones. In addition, the replacement of arylpiperazine fragment with tetrahydroisoquinoline in respective compounds caused increase of $\mathrm{p} K_{\mathrm{a}}$ values. The experimental $\mathrm{p} K_{\mathrm{a}}$ values are in range from 7.55 to 11.08 , the detail data are presented in Table 1 . The ranges of predicted $\mathrm{p} K_{\mathrm{a}}$ values of Pallas program are listed in Table 1. Unfortunately, the used program predicted no similar values to experimental $\mathrm{p} K_{\mathrm{a}}$ and could not diversify the acid-base properties of closely related compounds. In order to obtain more detailed relationships between acidbase properties of investigated compounds and the affinity of tested compounds to SERT, QSAR studies were undertaken. It was found linear correlation between affinities for SERT $\left(\mathrm{p} K_{\mathrm{i}}\right)$ and experimental $\mathrm{p} K_{\mathrm{a}}$ values (Fig. 1) but ratio of determination was moderate $\left(R^{2}=0.48\right.$ for sublibraries 1 and $R^{2}=0.38$ for sublibraries 2$)$.

Summarizing, two compounds 3 and $\mathbf{6}$ (derivatives of imidazo[2,1-f]purine-2,4-dione) are potent dual ligands for SERT and 5-HT ${ }_{1 \mathrm{~A}}$ receptor $\left(\mathrm{p} K_{\mathrm{i}}>7.5\right)$ and were classified to the further pharmacological studies. The obtained results confirm that the applied potentiometric method is useful in characterization of the acid-base properties of closely related compounds contrary to values of $\mathrm{p} K_{\mathrm{a}}$ predicted by Pallas program. There is no correlation between values of $\mathrm{p} K_{\mathrm{a}}$ predicted by Pallas program and experimental. The moderate correlation between activity for SERT and $\mathrm{p} K_{\mathrm{a}}$, indicating that acid-base properties are one of the important factors, which could influent and modify the activity for SERT.

Open Access This article is distributed under the terms of the Creative Commons Attribution Noncommercial License which permits any noncommercial use, distribution, and reproduction in any medium, provided the original author(s) and source are credited.

\section{References}

Adell A, Castro E, Celada P, Bortolozzi A, Pazos A, Artigas F (2005) Strategies for producing faster acting antidepressants. Drug Discov Ther 10:578-585

Artigas F, Romero L, de Montigny C, Blier P (1996) Acceleration of the effect of selected antidepressant drugs in major depression by 5- $\mathrm{HT}_{1 \mathrm{~A}}$ antagonists. Trends Neurosci 19:378-383

Ballesteros J, Callodo LF (2004) Effectiveness of pindolol plus serotonin uptake inhibitors in depression: a meta-analysis of early and late outcomes from randomized controlled trials. J Affect Disord 79:137-147

Barnes NM, Sharp T (1999) A review of central 5-HT receptors and their function. Neuropharmacology 38:1083-1152

Chaput Y, de Montingny C, Blier P (1986) Effects of selective 5-HT reuptake blocker, citalopram, on the sensitivity of 5-HT autoreceptors: electrophysiological studies in the rat brain. Naunyn Schmiedebergs Arch Pharmacol 333:342-348

Cheng YC, Prusoff WH (1973) Relationship between the inhibition constant (K1) and the concentration of inhibitor which causes 50 per cent inhibition (I50) of an enzymatic reaction. Biochem Pharmacol 22(23):3099-3108

Czopek A, Byrtus H, Kołaczkowski M, Pawłowski M, Dybała M, Nowak G, Tatarczyńska E, Wesołowska A, Chojnacka-Wójcik E (2010) Synthesis and pharmacological evaluation of new 5-(cyclo)alkyl-5-phenyl- and 5-spiroimidazolidine-2, 4-dione derivatives. Novel 5-HT1A receptor agonist with potential antidepressant and anxiolytic activity. Eur J Med Chem 45: 1295-1303

Filip M, Frankowska M, Zaniewska M, Gołda A (2005) The serotoninergic system and its role in cocaine addiction. Pharmacol Rep 57:685-700

Forrest LR, Tavoulari S, Zhang YW, Rudnick G, Honig B (2007) Identification of chloride ion binding site in $\mathrm{Na}^{+} / \mathrm{Cl}^{-}$dependent transporters. PNAS 104(31):12761-12766 
Goodson LH, Honigberg IL, Lehman JJ, Burton WH (1960) Potential growth antagonists. I. Hydantoins and disubstituted glycines. J Org Chem 25:1920-1924

Hannon J, Hoyer D (2008) Molecular biology of 5-HT receptors. Behav Brain Res 195:198-213

Hoyer D, Hannon JP, Martin GR (2002) Molecular, pharmacological and functional diversity of 5-HT receptors. Pharmacol Biochem Behav 71:533-554

Invernizzi R, Belli S, Samanin R (1992) Citalopram's ability to increase the extracellular concentrations of serotonin in the dorsal raphe prevents the drug's effect in the frontal cortex. Brain Res 584:322-324

Invernizzi R, Bramante M, Samanin R (1996) Role of 5-HT $1 \mathrm{~A}$ receptors in the effects of acute and chronic fluoxetine on extracellular serotonin in the frontal cortex. Pharmacol Biochem Behav 54:143-147

Lopez-Rodriguez ML, Ayala D, Benhamu B, Morcillo MJ, Viso A (2002) Arylpiperazine derivatives acting at $5-\mathrm{HT}_{1 \mathrm{~A}}$ receptors. Curr Med Chem 9:443-469

Luan F, Ma W, Zhang H, Zhang X, Liu M, Hu Z, Fan B (2005) Prediction of $\mathrm{p} K_{\mathrm{a}}$ for neutral and basic drugs based on radial basis function neural networks and their heuristic method. Pharm Res 22(9): 1454-1460

Manallack DT (2007) The $\mathrm{p} K_{\mathrm{a}}$ distribution of drugs: application to drug discovery. Perspect Med Chem 1:25-38

Millan PJ (2006) Multi-target strategies for the improved treatment of depressive states: conceptual foundations and neuronal substrates, drug discovery and therapeutic application. Pharmacol Ther 110:135-370
Morphy R, Rankovic Z (2005) Designed multiple ligands. An emerging drug discovery paradigm. J Med Chem 48(21): 6523-6543

Owens MJ, Morgan WN, Plott SJ, Nemeroff CB (1997) Neurotransmitter receptor and transporter binding profile of antidepressants and their metabolites. J Pharmacol Exp Ther 283(3):1305-1322

Paluchowska MH, Bugno R, Bojarski A, Charakchieva-Minol S, Duszyńska B, Tatarczyńska E, Kłodzińska A, Stachowicz K, Chojnacka-Wójcik E (2005) Novel, flexible, and conformationally defined analogs of gepirone: synthesis and 5- $\mathrm{HT}_{1 \mathrm{~A}}, 5-\mathrm{HT}_{2 \mathrm{~A}}$ and $\mathrm{D}_{2}$ receptor activity. Bioorganic Med Chem 13:1195-1200

Paluchowska MH, Bugno R, Duszyńska B, Tatarczyńska E, Nikiforuk A, Lenda T, Chojnacka-Wójcik E (2007) The influence of modifications in imide fragment structure on $5-\mathrm{HT}_{1 \mathrm{~A}}$ and $5-\mathrm{HT}_{7}$ receptor affinity and in vivo pharmacological properties of some new 1-( $m$-trifluoromethylphenyl)piperazines. Bioorganic Med Chem 15:7116-7125

Pauwels PJ (2003) 5-HT receptors and their ligands. Tocris Rev 25: $1-10$

Rudnick G, Kirk KL, Fishkes H, Schuldiner S (1989) Zwitterionic and anionic forms of serotonin analog as transport substrates. J Biol Chem 264(25):14865-14868

Zagórska A, Jurczyk S, Pawłowski M, Dybała M, Nowak G, Tatarczyńska E, Nikiforuk A, Chojnacka-Wójcik E (2009) Synthesis and preliminary pharmacological evaluation of imidazo[2, 1-f]purine-2, 4-dione derivatives. Eur J Med Chem 44: $4288-4296$ 